hold sessions. Dr. E. R. Weidlein, director of the Mellon Institute of Industrial Research, Pittsburgh, will deliver the annual presidential address of the Society on September 7. At the twenty-three symposia, the following subjects will be discussed: developments affecting industry, nutrition, public health, pure science, and education; artificial radioactivity and its chemical uses, studies of the chemistry of the earth's crust, low temperature methods and research, chemical microscopy, quantitative spectroscopic analysis, and photography; chemistry and physics of electrical insulation; medicinal patents, vitamins, and the chemistry and metabolism of fats ; cellulose derivatives; organic plastics; 'unit processes' and 'automatic control'; characteristic properties and chemical utilization of hydrocarbons; 'gaseous combustion'; investigations dealing with sugar, rubber, water, sewage, and sanitation, microchemistry, organic chemistry, fertilizers, and colloids.

\section{The Selborne By-Pass}

The Selborne Society, which for fifty-two years has cherished the memory of Gilbert White, invites admirers of his life and work to make a copy of the following protest and send it signed to the Secretary of the Selborne Society, The Hermitage, Hanwell, London, W.7, so that it may be forwarded to the proper authority with the Society's own: "Under. standing that powers are to be sought to drive a road, in the future, through the grounds of The Wakes at Selborne between the house and the Hanger which Gilbert White loved so well, I wish to protest against what would be an offence to the memory of a very great Englishman who made his village famous throughout the world and to urge that an alternative scheme, if necessary, be adopted.

\section{Indian Institute of Science, Bangalore.}

IT is reported in The Statesman (India) of July 21, that, at a meeting of the Governing Council of the Indian Institute of Science, Bangalore, held on the previous day, Sir C. V. Raman accepted the appointment of professor of physics at the Institute at a monthly salary of 2,500 rupees (£187). The Council has appointed an interim director on a monthly salary of 1,000 rupees for one year, in addition to a registrar on 1,250 rupees. Rao Bahadur B. Venkatesachar, a member of the Council, has taken over charge of the directorship from Sir C. V. Raman and the latter has thus been relieved of all administrative duties, including the secretaryship of the Governing Council. The registrar is Mr. C. E. W. Jones, formerly director of public instruction, Central Provinces, who took up his new duties on July 31. (See also NaturE of June 26, p. 1102.)

\section{'Vaseline' Products}

THE manager of the Chesebrough Manufacturing Co., Victoria Road, Willesden, London, N.W.10, writes to point out that the word 'vaseline' is wrongly used in a letter by Mr. L. Bellingham in NATURE of July 10, and in the summary of the letter. The word is not a common designation, but "is the trade mark or brand name used to distinguish the particular products marketed by this Company". The manager asks that the word 'vaseline' should not be used "unless in conjunction with and as the brand name applied to one of our products, such as 'Vaseline' Petroleum Jelly".

\section{A History of Chemistry}

AN interesting handbook issued by the Science Museum, London, S.W.7, entitled "Chemistry, a Brief Outline of its History and Development", by A. Barclay, gives an account of the history of chemistry, and is well illustrated, in some cases with representations of historical apparatus in the Museum. Apparatus used by Davy, Faraday, Graham, etc., is included. There are a good index and a bibliography. The subject is dealt with from the earliest period to modern times, the last section being on atomic structure. The handbook forms a useful and interesting supplement to text-books on chemistry. The price is $1 s .6 d$., post paid $1 s$. $8 d$., from the Museum or the sales offices of H.M. Stationery Office.

\section{Announcements}

The Baly Medal for 1937 of the Royal College of Physicians has been awarded to Prof. E. L. Kennaway, professor of experimental pathology in the University of London and director of the Research Institute of the Cancer Hospital (Free), London. The award is made in recognition of Prof. Kennaway's biochemical investigations, which have led to the identification of a group of substances provoking malignant growth of tissues and having significant relations in structure to certain hormones and vitamins.

THE Warren Research Fund Committee of the Royal Society has appointed G. S. Hartley, of University College, London, and J. T. Randall, of the General Electric Co., Ltd., to Warren research fellowships, each to be held for four years in the first instance. Mr. Hartley proposes to carry out research on oil drops, films and solutions, and Mr. Randall will undertake a research on the mechanism of fluorescence in pure and impure solids.

THe Ministry of Health has approved the application of the Birmingham Corporation for sanction to a loan of $£ 8,505$ for the provision of a forensic science laboratory for the detection of crime.

The publishers of Nature have in stock a certain number of bound volumes for which space can no longer be found. The volumes extend from vol. 1 to vol. 91, with the exception of the following: vols. 3, $8,15,17,19,22,23,24,25,51,53,74,76,77,79$, $80,83,84,85,86$. Librarians and others wishing to complete their sets of NATURE can be supplied with any of the volumes in stock, so long as the stock lasts, at the price of $2 s .6 d$. per volume, carriage paid. Application, with remittance, should be addressed to Nature Office, St. Martin's Street, London, W.C.2. Volumes which are not applied for by the end of this year will be destroyed. 